\title{
Chicory and Jerusalem Artichoke Productivity in Different Areas of Italy, in Relation to Water Availability and Time of Harvest
}

\author{
Mario Baldini ${ }^{1 *}$, Francesco Danuso ${ }^{1}$, Andrea Monti ${ }^{2}$, Maria Teresa Amaducci ${ }^{2}$, \\ Piergiorgio Stevanato ${ }^{3}$, Giuseppe De Mastro ${ }^{4}$ \\ ${ }^{1}$ Dipartimento di Scienze Agrarie ed Ambientali, Università di Udine \\ Via delle Scienze 208, 33100 Udine, Italia \\ ${ }^{2}$ Dipartimento di Scienze e Tecnologie Agroambientali \\ Viale Fanin 44, 40127 Bologna, Italia \\ ${ }^{3}$ Istituto Sperimentale per le Colture Industriali, ISCI \\ Viale Amendola 82, 45100 Rovigo, Italia \\ ${ }^{4}$ Dipartimento di Scienze delle Produzioni Vegetali \\ Via Amendola, 165/a 70125 Bari, Italia
}

Received: 23 March 2005. Accepted 17 March 2006

\begin{abstract}
Inulin is an important polysaccharide synthesised by different crops, which, in the EU has been included in the system of sugar quotas since 1994. Currently, one of the major problems of the agro-industry is the need to extend the length of the sugar crop harvest season. It was therefore decided, also in relation to the increased demand for inulin, to study the two main inulin producing crops in Italy (chicory and Jerusalem artichoke), to verify yield and quality potential and stability in relation to some important agronomic factors such as irrigation and time of harvest. The work was conducted in 1999 and 2000 in four areas of Italy (Udine, Rovigo, Bologna and Bari). The effects evaluated were time of harvest ( 3 for chicory and 2 for Jerusalem artichoke) and irrigation system (evapotranspiration replacement and dry regime, with irrigation applied only when strictly necessary) on the production of storage organs, sugars and inulin in the two crops. The highest chicory root yield was in Bologna, with an average production of $65.6 \mathrm{t} \mathrm{ha}^{-1}$ (fresh weight), compared to Rovigo (54.4 t ha-1), Bari (46.5 t ha-1) and Udine (38.7 $\mathrm{t}$ $\left.\mathrm{ha}^{-1}\right)$. For final tuber yield in Jerusalem artichoke, Bari was the most productive environment with an average of 80 $\mathrm{t} \mathrm{ha}^{-1}$, followed by Bologna $\left(61 \mathrm{t} \mathrm{ha}^{-1}\right)$ and Udine $\left(55.5 \mathrm{t} \mathrm{ha}^{-1}\right)$. However, when this crop is whole-plant harvested (stalks and tubers) at pre-flowering, Bologna, with high stalk yields $\left(58.7 \mathrm{t} \mathrm{ha}^{-1}\right)$ appeared to be the most suitable environment. This type of harvesting was also shown to be more productive in terms of sugar and inulin yield. The total sugar content in the different organs analysed (roots, stalk and tubers) was always higher in Udine compared to Bologna, for both crops. Lastly, the length of the inulin chain (average degree of polymerisation [DP]) diminishes with the delaying of the harvest in both crops. The Bologna area had the highest potential in terms of chicory root production, while for the tubers yield of Jerusalem artichoke, the Bari environment was the most productive. But, when Jerusalem artichoke is instead considered as a crop for whole-plant harvest (stalks and tubers), Bologna, with a very high stalk yields, becomes the most suitable area. The highest sugar content in roots, stalks and tubers of both crops was found in the Udine trial.
\end{abstract}

Key-words: Jerusalem artichoke, chicory, sugars, inulin, production.

\section{Introduction}

Chicory and Jerusalem artichoke can be considered as both sugar and dietary fibre crops, as they accumulate in their roots, tubers and stalks, linear polymers of fructose (fructans, also known as inulin) with a highly variable degree of polymerisation (4-150 DP), which affects their end-use. Fructans with low DP and fructose, obtained by hydrolysis of the fructans, are often used directly as dietary fibres or else as low-calorie sweetening syrups, while inulins with high DP (10-30) are used entirely for industrial and non-food uses such as pharmaceuticals and cosmetics (Fuchs, 1993; Danuso, 2001). In the 
EU, inulin has been included in the system of sugar quotas since 1994. From 2001/2002 to 2005/2006, these quotas have been assigned exclusively to the Netherlands, France and Belgium, for a total of 320,000 $\mathrm{t}$ (white sugar equivalents) obtained from chicory.

One of the main problems of today's sugar processing industry is the need to extend the harvest season, in particular bringing it forward, with compensation given to farmers for the lower yield of earlier harvests. It was therefore decided, because of the increased interest in inulin crops, to study chicory outside the current growing areas, in order to verify the yield stability potential and quality in Italy. Jerusalem artichoke is today relegated to small areas principally for the production of tubers for human or livestock consumption, so there could be interesting prospects for high earning potential with an early whole-plant harvest (stalks + tubers). This harvesting method has always produced higher yields than the traditional harvest of tubers alone, with the agronomic advantage of freeing the land earlier (Paolini et al., 1996; Baldini et al., 2004). However there are still problems connected to the perfecting of harvesting machinery (for stalks) and new ways of processing the harvested produce. The inclusion of chicory and Jerusalem artichoke in Italian rotations would enhance current cropping systems and provide a good alternative to sugarbeet if the raw material can be produced at competitive prices. Moreover, from the agro-ecological aspect, it is always desirable to have at least one alternative crop for each raw material, instead of a single main crop used for more than one purpose (Schittenhelm, 1999).

Other studies have evaluated chicory and Jerusalem artichoke in Italy (Paolini et al., 1996; Di Candilo et al., 1997; Amaducci and Pritoni, 1998; Danuso et al., 2002), looking at different varieties, comparing cropping techniques and evaluating alternative uses at harvest (D'Egidio et al., 1998), but always separately, while little has been done in terms of a comparison between the two species in different areas of the country.

This was why the question of inulin crops was tackled in Italy in a PRIN (MIUR) project entitled "Colture per la produzione di inulina: modelli di risposta ambientale e strategie colturali" 1999-2000. This paper presents the results of a two-year experiment conducted within the framework of this project, and reports the yield response of chicory and Jerusalem artichoke in different Italian growing areas, in relation to some important agronomic factors such as irrigation and harvesting time.

\section{Materials and methods}

Trials on chicory and Jerusalem artichoke were conducted over the two years 1999-2000, by the Working Groups taking part in the project, in four areas of Italy (Table 1). In each environment the effects of two different production factors were evaluated: time of harvest ( 3 for chicory and 2 for Jerusalem artichoke); irrigation regime with two treatments: a) replacement of evapotranspiration and b) dry regime, with irrigation applied only when strictly necessary. Treatment b) varied from area to area according to the pedo-climatic conditions; in Bari $25 \%$ of evapotranspiration was replaced, and necessary irrigations were applied in Udine and Rovigo, while there was no irrigation in Bologna. Temperature and rainfall patterns are reported in Figure 1, the main soil characteristics in Table 2, agronomic techniques in Tables 3 and 4, with Figure 2 showing the pattern of soil moisture content, and Figure 3 the number of irrigations and amounts of water applied.

The chicory variety "Bergues" was used, which was precision sown (in some cases followed by manual thinning) in rows $0.50 \mathrm{~m}$ apart and with plants $0.13 \mathrm{~m}$ apart on the row, for a

Table 1. Working Groups and locations of the experimental sites.

\begin{tabular}{|c|c|c|c|c|}
\hline Working Groups & Locations & Altitude $\mathrm{m}$ a.s.l. & Latitude & Longitude \\
\hline University of Udine & Udine & 110 & $46^{\circ} 03^{\prime} \mathrm{N}$ & $13^{\circ} 13^{\prime} \mathrm{E}$ \\
\hline ISCI, Rovigo section & Rovigo & 7 & $45^{\circ} 04^{\prime} \mathrm{N}$ & $11^{\circ} 47^{\prime} \mathrm{E}$ \\
\hline University of Bologna & Cadriano (BO) & 33 & $44^{\circ} 30^{\prime} \mathrm{N}$ & $11^{\circ} 20^{\prime} \mathrm{E}$ \\
\hline University of Bari & Policoro (BA) & 31 & $40^{\circ} 20^{\prime} \mathrm{N}$ & $16^{\circ} 70^{\prime} \mathrm{E}$ \\
\hline
\end{tabular}


Table 2. Main soil characteristics of the experimental sites.

\begin{tabular}{lcccc}
\hline & Udine & Rovigo & Cadriano (BO) & Policoro (BA) \\
\hline pH & 7.8 & 7.9 & 7.8 & 7.7 \\
Organic matter (\%) & 2.9 & 2.2 & 1.3 & 3.6 \\
Total N (\%) & 1.9 & 2.1 & 1.0 & 1.7 \\
Assimilable P (ppm) & 41 & 11 & 66 & 27 \\
Exchangeable K (ppm) & 200 & 116 & 175 & 227 \\
Total lime (\%) & 3 & 8 & 21 & 40 \\
Sand (\%) & 43 & 5 & 53 & 37 \\
Silt (\%) & 40 & 52 & 25 & 23 \\
Clay (\%) & 17 & 43 & & \\
\hline
\end{tabular}

Table 3. Main cropping management techniques adopted for Chicory.

\begin{tabular}{|c|c|c|c|c|c|c|c|c|}
\hline & $\begin{array}{l}\text { Bari } \\
1999\end{array}$ & $\begin{array}{l}\text { Bari } \\
2000\end{array}$ & $\begin{array}{l}\text { Bologna } \\
1999\end{array}$ & $\begin{array}{l}\text { Bologna } \\
2000\end{array}$ & $\begin{array}{l}\text { Udine } \\
1999\end{array}$ & $\begin{array}{l}\text { Udine } \\
2000\end{array}$ & $\begin{array}{l}\text { Rovigo } \\
1999\end{array}$ & $\begin{array}{l}\text { Rovigo } \\
2000\end{array}$ \\
\hline Previous crop & cotton & artichoke & wheat & wheat & sunflower & clover & set aside & hemp \\
\hline Soil tillage & $\begin{array}{l}\text { ploughing at } \\
40 \mathrm{~cm}+ \\
\text { harrowing (2) }\end{array}$ & $\begin{array}{l}\text { ploughing at } \\
40 \mathrm{~cm} \text {, } \\
\text { harrowing (2), }\end{array}$ & $\begin{array}{l}\text { ploughing } \\
\text { at } 30 \mathrm{~cm} \text {, } \\
\text { harrowing, } \\
\text { pre-sowing } \\
\text { rolling packer }\end{array}$ & $\begin{array}{l}\text { ploughing } \\
\text { at } 30 \mathrm{~cm} \text {, } \\
\text { harrowing, } \\
\text { pre-sowing } \\
\text { rolling packer }\end{array}$ & $\begin{array}{l}\text { ploughing at } \\
40 \mathrm{~cm} \text {, } \\
\text { harrowing (2) }\end{array}$ & $\begin{array}{l}\text { ploughing at } \\
40 \mathrm{~cm} \text {, } \\
\text { harrowing (2) }\end{array}$ & $\begin{array}{l}\text { ploughing at } \\
40 \mathrm{~cm} \text {; weed } \\
\text { ring; till ring; } \\
\text { harrowing }\end{array}$ & $\begin{array}{l}\text { ploughing } \\
\text { at } 40 \mathrm{~cm} \text {; weed } \\
\text { ring; till ring; } \\
\text { harrowing }\end{array}$ \\
\hline $\begin{array}{l}\text { Fertilization } \\
(\text { as } \mathrm{Kg} / \mathrm{ha} \mathrm{N} \text {, } \\
\left.\mathrm{P}_{2} \mathrm{O}_{5}, \mathrm{~K}_{2} \mathrm{O}\right)\end{array}$ & $\begin{array}{l}\text { pre-sowing } \\
+ \text { post- } \\
\text { emergence }(\mathrm{N}) \text {, } \\
150-120-0\end{array}$ & $\begin{array}{l}\text { pre-sowing } \\
+ \text { post- } \\
\text { emergence }(\mathrm{N}) \text {, } \\
150-120-0\end{array}$ & $\begin{array}{l}\text { pre-sowing } \\
+ \text { post- } \\
\text { emergence }(\mathrm{N}) \text {, } \\
100-100-0\end{array}$ & $\begin{array}{l}\text { pre-sowing } \\
+ \text { post- } \\
\text { emergence }(\mathrm{N}) \text {, } \\
100-100-0\end{array}$ & $\begin{array}{l}\text { pre-sowing } \\
80-200-200\end{array}$ & $\begin{array}{l}\text { pre-sowing } \\
80-0-125\end{array}$ & $\begin{array}{l}\text { pre-sowing } \\
130-80-190\end{array}$ & $\begin{array}{l}\text { pre-sowing } \\
130-80-190\end{array}$ \\
\hline Sowing time & $12 / 4$ & $30 / 03$ & $12 / 4$ & $14 / 4$ & $29 / 03$ & $10 / 04$ & $06 / 04$ & $13 / 04$ \\
\hline $\begin{array}{l}\text { Emergence } \\
\text { time }\end{array}$ & $03 / 05$ & $02 / 05$ & $01 / 05$ & $05 / 05$ & $09 / 04$ & $20 / 04$ & $20 / 04$ & $02 / 05$ \\
\hline Weed control & $\begin{array}{l}\text { by hand } \\
+ \text { hoeing }\end{array}$ & $\begin{array}{l}\text { by hand } \\
+ \text { hoeing }\end{array}$ & hoeing & hoeing & $\begin{array}{l}\text { by hand } \\
+ \text { hoeing }(2)\end{array}$ & $\begin{array}{l}\text { by hand } \\
+ \text { hoeing (2) }\end{array}$ & by hand & $\begin{array}{l}\text { Propaquizafop } \\
\text { post-emer. + by } \\
\text { hand } 1\end{array}$ \\
\hline $\begin{array}{l}\text { Pesticide } \\
\text { treatments }\end{array}$ & $\begin{array}{l}\text { Chlorothalonil } \\
+ \text { Azinphos } \\
\text {-methyl }\end{array}$ & none & none & none & none & none & none & $\begin{array}{l}\text { Azinphos - } \\
\text { methyl }\end{array}$ \\
\hline Harvest times & $\begin{array}{l}1^{\circ} \text { on } 22 / 09 \\
2^{\circ} \text { on } 26 / 10 \\
3^{\circ} \text { on } 29 / 11\end{array}$ & $\begin{array}{l}1^{\circ} \text { on } 11 / 10 \\
2^{\circ} \text { on } 17 / 11 \\
3^{\circ} \text { on } 05 / 12\end{array}$ & $\begin{array}{l}1^{\circ} \text { on } 01 / 09 \\
2^{\circ} \text { on } 12 / 10 \\
3^{\circ} \text { on } 01 / 12\end{array}$ & $\begin{array}{l}1^{\circ} \text { on } 06 / 09 \\
2^{\circ} \text { on } 10 / 10 \\
3^{\circ} \text { on } 07 / 11\end{array}$ & $\begin{array}{l}1^{\circ} \text { on } 22 / 09 \\
2^{\circ} \text { on } 02 / 11 \\
3^{\circ} \text { on } 25 / 11\end{array}$ & $\begin{array}{l}1^{\circ} \text { on } 19 / 09 \\
2^{\circ} \text { on } 23 / 10 \\
3^{\circ} \text { on } 27 / 11\end{array}$ & $\begin{array}{l}1^{\circ} \text { on } 24 / 09 \\
2^{\circ} \text { on } 30 / 10 \\
3^{\circ} \text { on } 18 / 11\end{array}$ & $\begin{array}{l}1^{\circ} \text { on } 15 / 09 \\
2^{\circ} \text { on } 27 / 10\end{array}$ \\
\hline
\end{tabular}

density of 15 plants $\mathrm{m}^{-2}$. The trial design was split-plot with 4 replications, with irrigation treatments as the main plots and times of harvest as sub-plots. The experimental unit was a minimum of 8 to a maximum of 12 rows, from 8 to 10 metres in length for an area that ranged, according to environment, from 36 to $48 \mathrm{~m}^{2}$. The harvests, always done manually, were on an area of $5 \mathrm{~m}^{2}$, and the following characteristics were determined on the produce obtained: roots fresh weight $\left(\mathrm{t} \mathrm{ha}^{-1}\right)$; dry matter content in the roots $(\%)$; leaves dry weight ( $\left.\mathrm{t} \mathrm{ha}^{-1}\right)$; total sugar content in the roots at harvest (\%); production of total sugars $\left(\mathrm{t} \mathrm{ha}^{-1}\right)$; production of inulin $\left(\mathrm{t} \mathrm{ha}^{-1}\right)$; average degree of polymerisation of the inulin
(DP). Only root production was determined in Rovigo, while leaf production was not measured in Udine.

For Jerusalem artichoke, which was not included in Rovigo, the variety "Violetto di Rennes" was used. Sowing was conducted manually, planting the tubers (average weight 50-70 $\mathrm{g}$ each) at a depth of 3-4 cm, in rows $0.7 \mathrm{~m}$ apart and with a distance between plants on the row of $0.25 \mathrm{~m}$ (0.20 m in Bologna), giving a sowing density of 5.7 tubers $\mathrm{m}^{-2}$ in Bari and Udine and 7 tubers $\mathrm{m}^{-2}$ in Bologna. The trial design was split-plot with 4 replications, with the irrigation treatments as the main plots and times of harvest as sub-plots. The experimental unit was 5 
Baldini M., Danuso F., Monti A., Amaducci M.T., Stevanato P., De Mastro G.

Table 4. Main cropping management techniques adopted for Jerusalem artichoke.

\begin{tabular}{|c|c|c|c|c|c|c|}
\hline & Bari 1999 & Bari 2000 & Bologna 1999 & Bologna 2000 & Udine 1999 & Udine 2000 \\
\hline Previous crop & cotton & artichoke & wheat & wheat & sunflower & Set asides \\
\hline Soil tillage & $\begin{array}{l}\text { ploughing at } 40 \mathrm{~cm} \text {, } \\
2 \text { harrowing }(2)\end{array}$ & $\begin{array}{l}\text { ploughing at } 40 \mathrm{~cm} \text {, } \\
2 \text { harrowing }(2)\end{array}$ & $\begin{array}{l}\text { ploughing at } 30 \mathrm{~cm} \text {, } \\
\text { harrowing, pre- } \\
\text { planting puckering }\end{array}$ & $\begin{array}{l}\text { ploughing at } 30 \mathrm{~cm} \text {, } \\
\text { harrowing, pre- } \\
\text { planting puckering }\end{array}$ & $\begin{array}{l}\text { ploughing at } 40 \mathrm{~cm} \text {, } \\
\text { harrowing (2) }\end{array}$ & $\begin{array}{l}\text { ploughing at } 40 \mathrm{~cm} \text {, } \\
\text { harrowing (2) }\end{array}$ \\
\hline $\begin{array}{l}\text { Fertilization } \\
\text { (as } \mathrm{Kg} / \mathrm{ha} \mathrm{N}, \\
\left.\mathrm{P}_{2} \mathrm{O}_{5}, \mathrm{~K}_{2} \mathrm{O}\right)\end{array}$ & $\begin{array}{l}\text { pre-sowing }+ \\
\text { post-emergence }(\mathrm{N}) \text {, } \\
150-120-0\end{array}$ & $\begin{array}{l}\text { pre-sowing }+ \\
\text { post-emergence }(\mathrm{N}) \text {, } \\
150-120-0\end{array}$ & $\begin{array}{l}\text { pre-sowing }+ \\
\text { post-emergence }(\mathrm{N}) \text {, } \\
100-100-0\end{array}$ & $\begin{array}{l}\text { pre-sowing }+ \\
\text { post-emergence }(\mathrm{N}) \text {, } \\
100-100-0\end{array}$ & $\begin{array}{l}\text { pre-sowing } \\
80-200-200\end{array}$ & $\begin{array}{l}\text { pre-sowing } \\
80-0-125\end{array}$ \\
\hline Sowing time & $12 / 4$ & $27 / 03$ & - & - & $25 / 03$ & $21 / 03$ \\
\hline Emergence time & $29 / 04$ & $28 / 04$ & $11 / 04$ & $16 / 04$ & $08 / 04$ & $21 / 04$ \\
\hline Weed control & by hand + hoeing & by hand + hoeing & hoeing & hoeing & by hand & by hand \\
\hline $\begin{array}{l}\text { Pesticide } \\
\text { treatments }\end{array}$ & $\begin{array}{l}\text { Chlorothalonil } \\
+ \text { Azinphos -methyl }\end{array}$ & none & none & none & none & none \\
\hline Harvest times & $\begin{array}{l}1^{\circ} \text { on } 5 / 10 \\
2^{\circ} \text { on } 29 / 12\end{array}$ & $\begin{array}{l}1^{\circ} \text { on } 18 / 10 \\
2^{\circ} \text { on } 18 / 12\end{array}$ & $\begin{array}{l}1^{\circ} \text { on } 29 / 09 \\
2^{\circ} \text { on } 01 / 12\end{array}$ & $\begin{array}{l}1^{\circ} \text { on } 25 / 09 \\
2^{\circ} \text { on } 07 / 11\end{array}$ & $\begin{array}{l}1^{\circ} \text { on } 04 / 10 \\
2^{\circ} \text { on } 02 / 12\end{array}$ & $\begin{array}{l}1^{\circ} \text { on } 11 / 10 \\
2^{\circ} \text { on } 04 / 12\end{array}$ \\
\hline
\end{tabular}

rows of 12 metres in length in Bologna, giving an area of $42 \mathrm{~m}^{-2}$, and 8 rows, 8 metres long in Udine and Bari for an area of $44.8 \mathrm{~m}^{-2}$. Harvesting, always done manually, was of an area of $9.8 \mathrm{~m}^{-2}$ in Udine and Bari in 1999, and $5 \mathrm{~m}^{-2}$ in Bologna and Bari in 2000.

At both harvesting times (the first for stalks and tubers, the second only for tubers), the following characteristics were determined: tuber and stalk yield ( $\left.\mathrm{t} \mathrm{ha}^{-1}\right)$; tuber and stalk dry matter content $(\%)$; total sugar content in tubers and stalks $(\%)$; total sugar production $\left(\mathrm{t} \mathrm{ha}^{-1}\right)$; production of inulin $\left(\mathrm{t} \mathrm{ha}^{-1}\right)$; average degree of polymerisation of the inulin (DP). In both chicory and Jerusalem artichoke, sugars were only analysed in Udine and Bologna, and in the latter, only at the 1st and 2nd harvests in 2000. To extract fructans (inulin), $1 \mathrm{~g}$ of sample was mixed with $10 \mathrm{ml}$ of distilled water at $85{ }^{\circ} \mathrm{C}$ for $3 \mathrm{~h}$, with gentle shaking. The solution was cooled to room temperature, adjusted to $10 \mathrm{ml}$, homogenised and filtered through a $45 \mathrm{~mm}$ membrane filter. The free sugars (sucrose, glucose and fructose) were analysed by the HPLC method, using a Bio-Rad Aminex HPX-87C column (Bio-Rad Laboratories, Milan, Italy) run at $85{ }^{\circ} \mathrm{C}$ with degassed HPLC-grade water at a flow rate of $0.6 \mathrm{ml} \mathrm{min}{ }^{-1}$ and an injection volume of $20 \mathrm{ml}$. Carbohydrates were detected by a Waters 410 refractive index detector (Millipore Corporation, Milford, USA). To determine the total fructose and glucose content, $1 \mathrm{~g}$ of fresh sample was hydrolysed with hydrochloric acid $(0.2 \mathrm{M})$ at $85{ }^{\circ} \mathrm{C}$ for $2 \mathrm{~h}$, and then neutralised with sodium hydroxide. After centrifugation for $10 \mathrm{~min}$ at $1400 \mathrm{rpm}$, the sample was filtered and adjusted to $10 \mathrm{ml}$, and the fructose and glucose released by hydrolysis were determined by the HPLC method. Total glucose and fructose per hectare were calculated by multiplying storage fresh matter yield by the total glucose and fructose content, respectively. The inulin content was obtained by: $I=(F+G)-(f g$ $+f f+f s)$, where $\mathrm{F}$ and $\mathrm{G}$ are the total content of fructose and glucose, respectively, and $f g, f f$ and $f s$ are the content of free glucose, free fructose and free glucose, respectively.

The fructose/glucose ratio, strictly related to the average inulin chain length, (Van Waes et al., 1998), is reported in the text as the average degree of polymerisation (DP).

ANOVA was used for statistical analysis, keeping environments and species separate. The experimental design was split-plot with 4 replications, considering years as casual effect and water regime (irrigation and dry) and times of harvest (three for chicory and two for Jerusalem artichoke), as fixed.

\section{Results and discussion}

\subsection{Chicory}

3.1.1 Root production. In Bologna the average fresh weight yield of chicory roots was $65.6 \mathrm{t} \mathrm{ha}^{-1}$. There was a significant effect of the interaction 


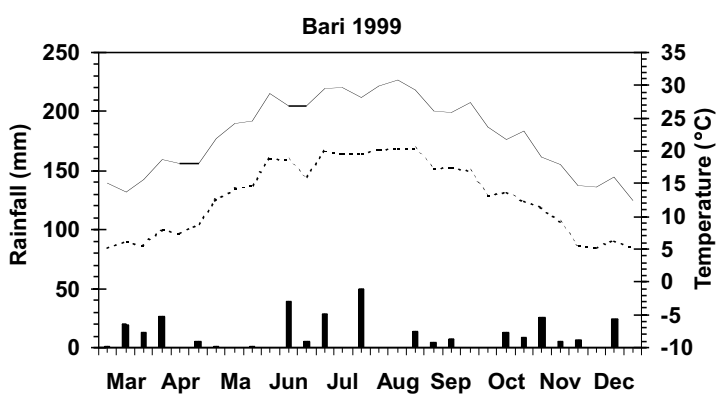

rainfall $\longrightarrow$ Tmax $\cdots \cdots \ldots$ Tmin

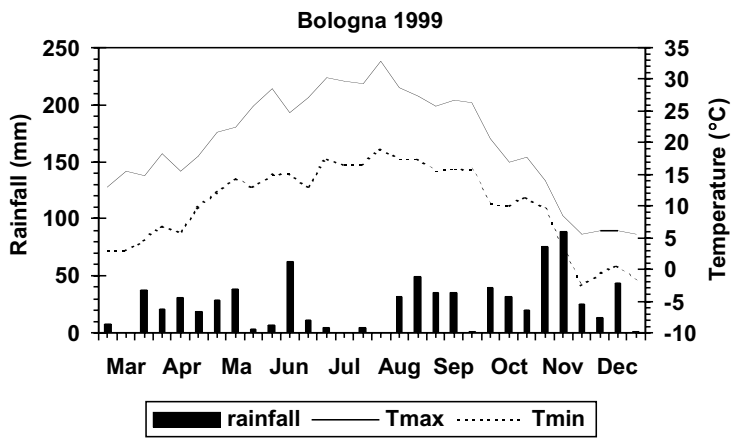

Rovigo 1999

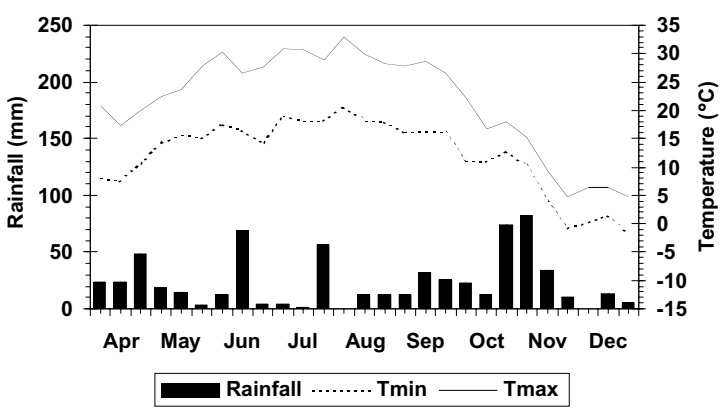

Udine 1999

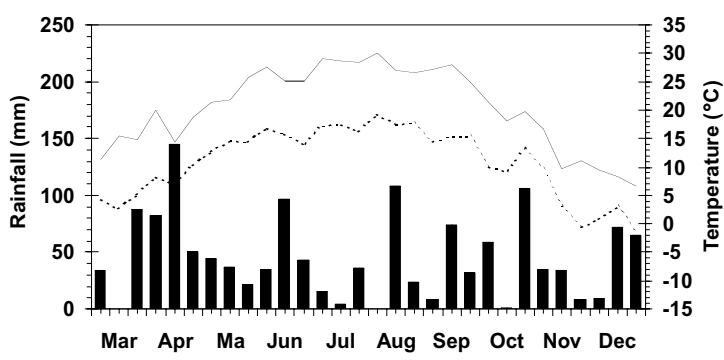

Rainfall ......... Temp min — Tem Max

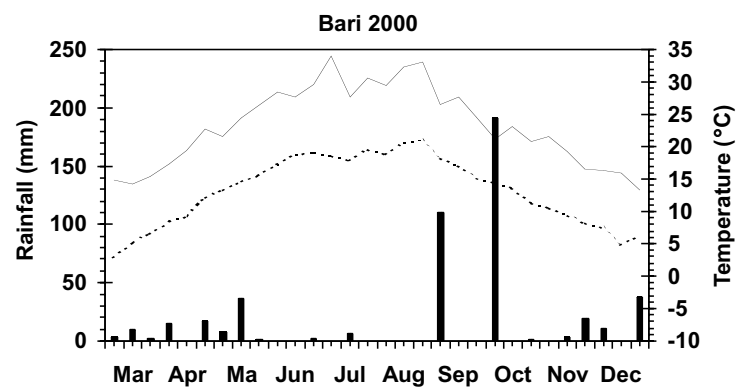

rainfall …..... Tmin $\longrightarrow$ Tmax

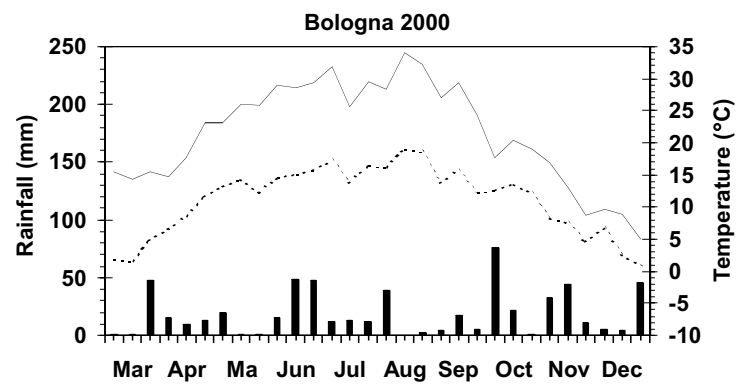

rainfall $\longleftarrow$ Tmax $\cdots \cdots \ldots$ Tmin

Rovigo 2000

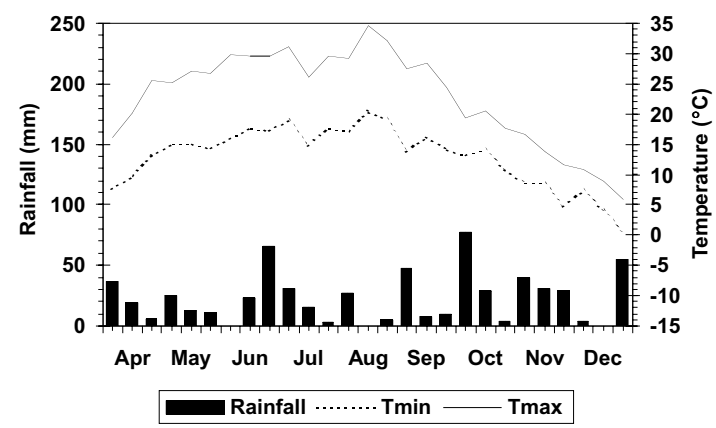

Udine 2000

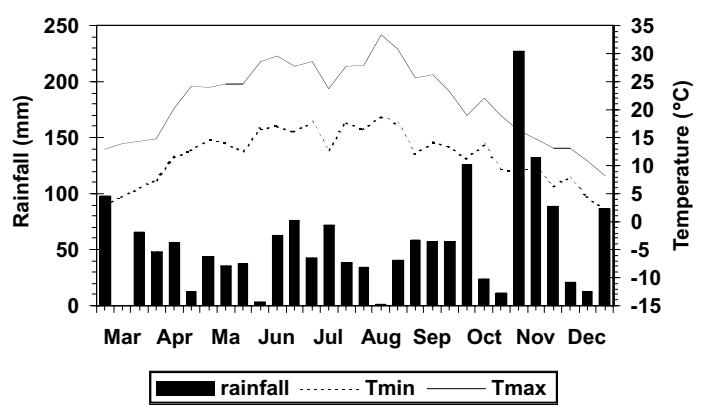

Figure 1. Ten-day rainfall, maximum and minimum temperature recorded at the experiment sites during 1999 and 2000.

year $\mathrm{x}$ harvest time, determined by the high root yield of $85.3 \mathrm{t} \mathrm{ha}^{-1}$ recorded at the 3rd harvesting time in 1999 (compared to yields of 54.9 and $66.6 \mathrm{t} \mathrm{ha}^{-1}$ of the others) (Figure 4). This was well above the yield obtained in previous experiments in the same environment with the same variety (55.3 $\mathrm{t} \mathrm{ha}^{-1}$ ) (Amaducci and Pritoni, 1998) and also the maximum yields ob- 

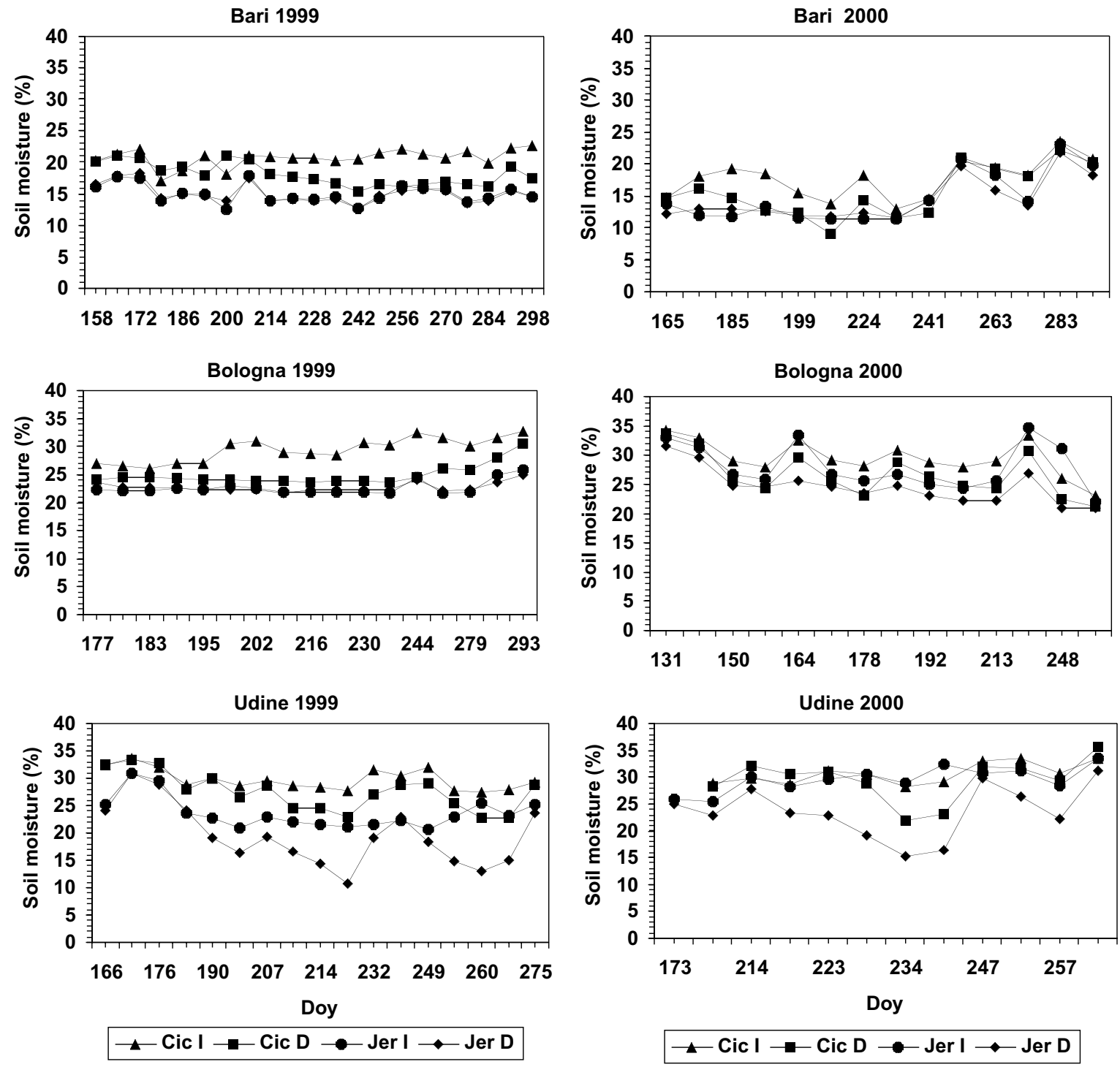

Figure 2. Soil moisture (as \% of volume) at $40 \mathrm{~cm}$ of depth recorded at the experiment sites during 1999 and 2000 (doy = day of the year). $\mathrm{I}=$ with irrigation, $\mathrm{D}=$ dry regime. Cic $=$ Chicory, Jer $=$ Jerusalem artichoke.

tained with the same variety in other areas $(68.8$ $\mathrm{t} \mathrm{ha}^{-1}$ ) (Schittenhelm, 1999 and 2001). The explanation for this is the higher moisture content percentage in the roots, probably associated with a favourable rainfall pattern during the year and low temperatures in the second half of November (with minimums below $0{ }^{\circ} \mathrm{C}$ ) (Figure 1 ), which encouraged the translocation of assimilates from the aerial parts of the plant to the root, reducing the respiratory processes of the latter and preventing any late fungal attacks (Van Herck et al., 1992). Previous trials (Amaducci and Pritoni, 1998) had reported the har- vest time for chicory in this area as being September-October, whereas later harvests have been tested in this trial, such as the 3rd one in 1999 (on 2 December), which produced the above-mentioned result. Similar results were obtained by Baert (1997) in two years of trials, where, although in a different environment with other varieties, the later harvest among those tested (November, against September-October) corresponded to higher yields, even if not always significantly.

Rainfall differed during the cropping cycles in the two years (660 and $462 \mathrm{~mm}$ in 1999 and 

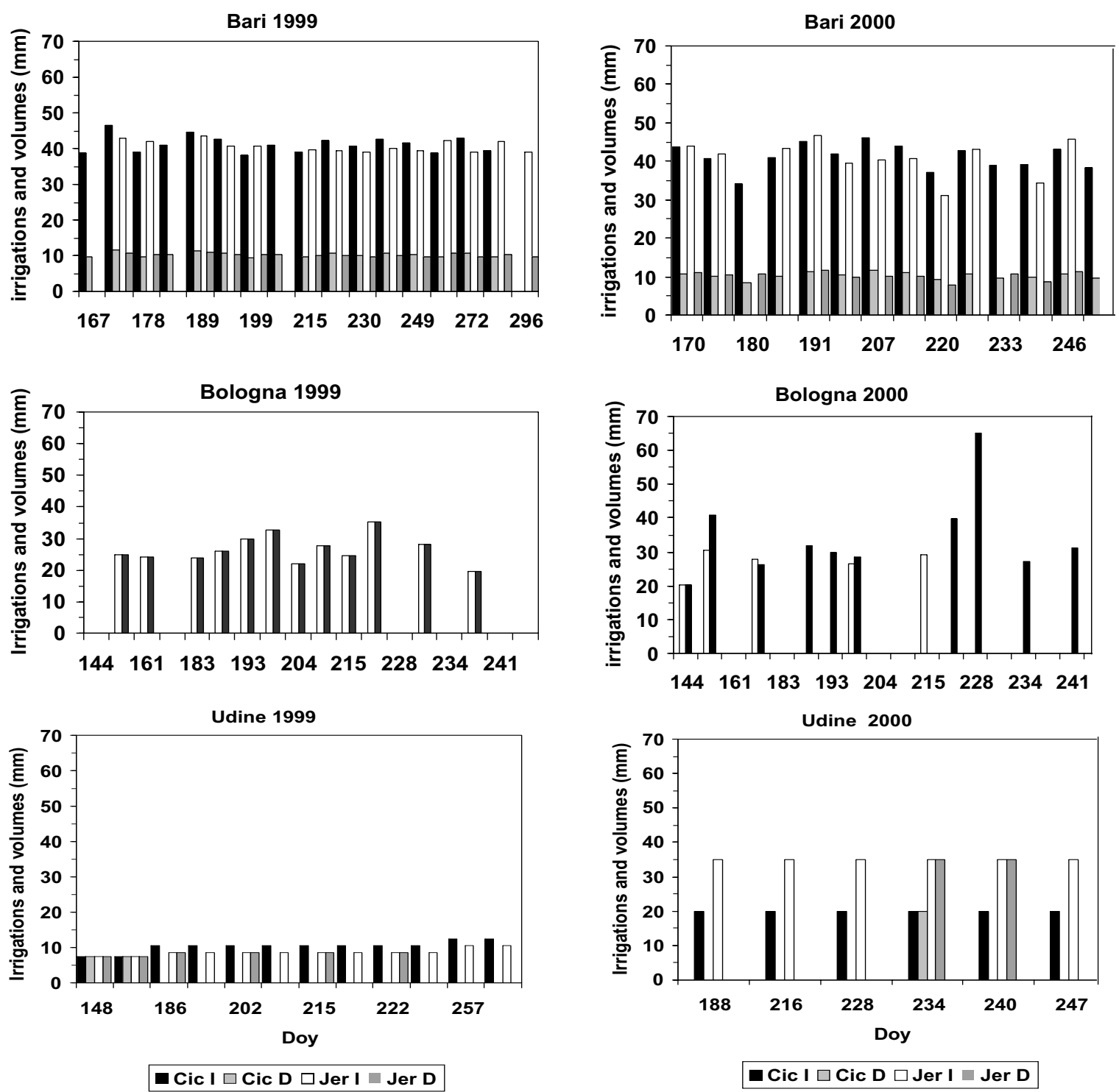

Figure 3. Number of irrigations (number of bars) and related volumes performed at the experimental sites during 1999 and 2000 (doy= day of the year). $\mathrm{I}=$ with irrigation, $\mathrm{D}=$ dry regime. Cic $=$ Chicory, Jer $=$ Jerusalem artichoke.

2000, respectively). Adding these values to the volumes received by the irrigated treatments (318 and $134 \mathrm{~mm}$ in the 1st and 2nd year, respectively), the total water availability in 1999 $(978 \mathrm{~mm})$ is almost double that in 2000 (596 $\mathrm{mm}$ ) (Figure 1). The different rainfall trend in 1999 significantly influenced the differences in soil moisture content between irrigated and dry treatments (29.4 against $24.9 \%$ ), while these differences were much less in 2000 (29.5 and $26.6 \%$ ) (Figure 2).

In Udine in 1999 a first sowing conducted on 25/03 failed, while in 2000 there was a serious attack of Sclerotinia spp. at the 2nd and 3rd harvesting times. There were very few pre-flowering plants, in the order of $2-3 \%$.

In Udine, the root yield in the trial ranged between 34.5 and $46.6 \mathrm{t} / \mathrm{ha}$. At the 3 rd harvest (331 doy) in 2000, there was a clear and significant yield reduction (20.8 tha-1), which resulted in a statistical significance of the interaction year $\mathrm{x}$ harvest time (Figure 4). The excessive rainfall in the first 20 days of November (360 $\mathrm{mm}$ ), accompanied by mild temperatures (average $5{ }^{\circ} \mathrm{C}$ ) (Figure 1), anomalous in that environment, determined a process of re-growth, ac- 
a)
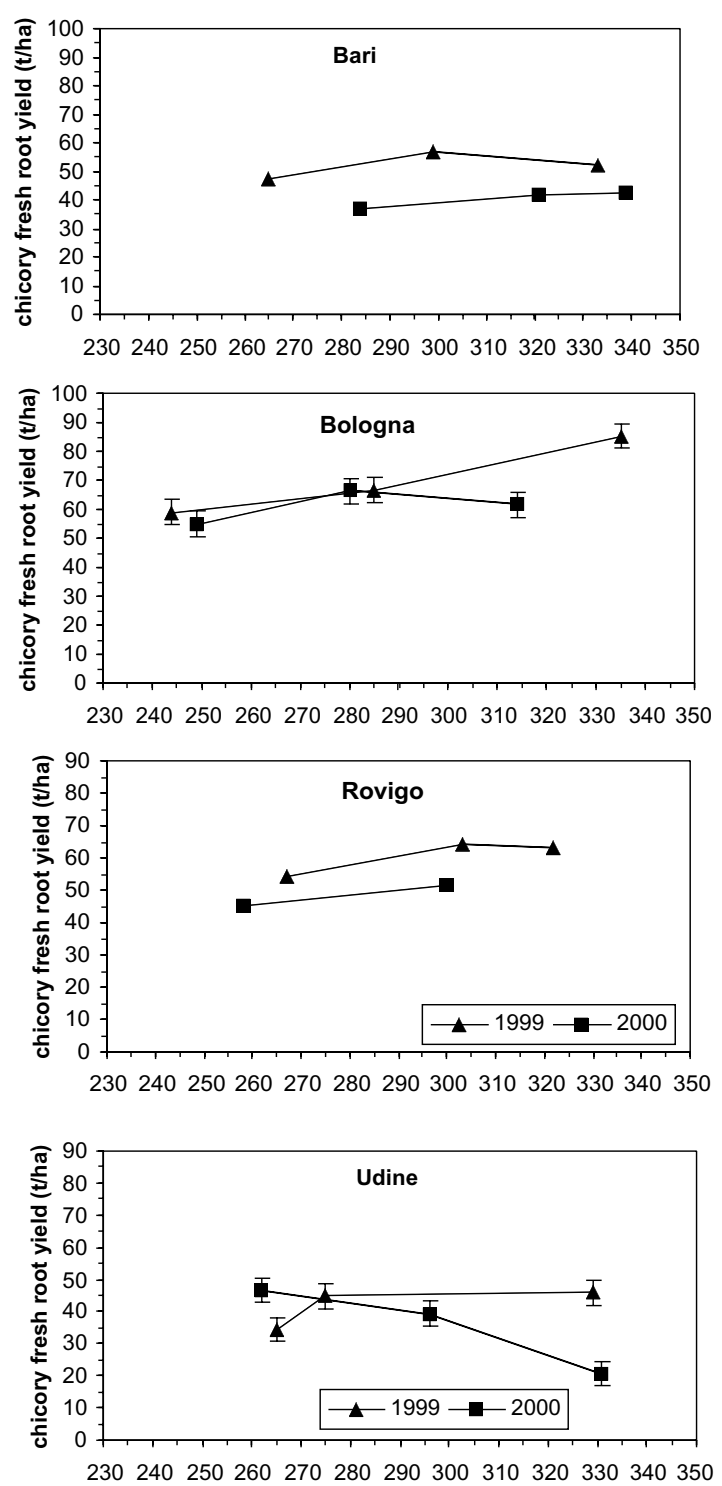

b)

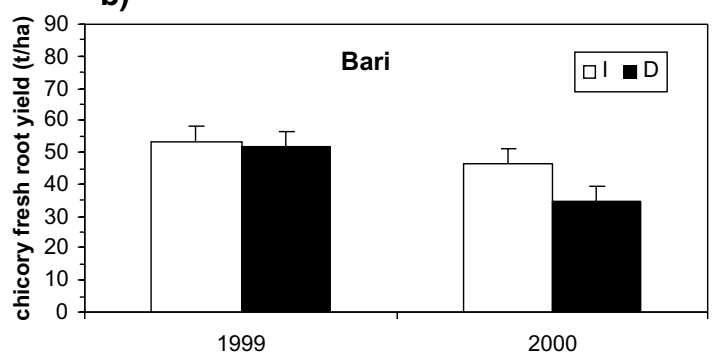

Figure 4. Effects of the interaction Harvest time $\mathrm{x}$ Year (a) and Irrigation regime $\mathrm{x}$ Year at Bari (b), on root yield of Chicory, during 1999 and 2000. (doy= day of the year). Symbols represent the three harvest times. I = with irrigation; $\mathrm{D}=$ dry regime. Bars represent L.S.D. for $\mathrm{P}<0.05$, where not present the interaction is not significant. companied by a serious attack of Sclerotinia spp. which partially destroyed the above-ground plant parts, with negative influences on nutrient storage in the root, probably caused by a process of inverse translocation.

In this area, the soil has a very shallow active layer (generally less than $50 \mathrm{~cm}$ ) which, with a high gravel fraction ( $>15 \%)$ and more than $40 \%$ of sand (Table 2), means that the soil has low water retention capacity. Therefore, despite the high rainfall during the crop cycle (1100 and $1400 \mathrm{~mm}$ in 1999 and 2000, respectively), it was necessary to irrigate frequently with fairly low volumes where this was included in the trial (12 and 6 irrigations in the 1st and 2nd year, respectively), for a total of 124 and $120 \mathrm{~mm}$ in 1999 and 2000, respectively. Some irrigations were also necessary in the "dry" treatment: 2 in 1999, for a total of $15 \mathrm{~mm}$ to encourage crop germination, and one in 2000 of $20 \mathrm{~mm}$, during a period of serious water deficit in August (Figure 3). This is confirmed by the fact that the soil moisture content during the crop cycle remained around $30 \%$ on average in the irrigated treatments, while in the dry treatments it ranged from $27.5 \%$ to $23 \%$ in 1999 and from $29.5 \%$ to $22 \%$ in 2000 (Figure 2). In Bari, an environment with high temperatures and low rainfall (totals of 240 and $400 \mathrm{~mm}$ in 1999 and 2000, respectively) (Figure 1), average yield was $46.5 \mathrm{t} \mathrm{ha}^{-1}$ and the interaction year $\mathrm{x}$ irrigation treatment was significant, demonstrating a yield difference determined by the two irrigation regimes in 2000 (46.5 and $34.7 \mathrm{t} \mathrm{ha}^{-1}$ in irrigated and dry, respectively) (Figure 4). During the summer months of 2000 (June, July and August) only $8.5 \mathrm{~mm}$ of rain fell, and the water table ranged between depths of 2.2-3.7 $\mathrm{m}$ during the cropping cycle, which was too deep for the crop. Temperatures were on average higher than the previous year, as shown by the temperature sum (with $0{ }^{\circ} \mathrm{C}$ as base temperature) calculated from April to November (3406 vs. $3269^{\circ} \mathrm{Cd}$ ). In 1999 , $135 \mathrm{~mm}$ of rain fell in the same three summer months: enough, together with a shallower water table (1.6-2.8 m deep), to render irrigation irrelevant and give higher yields (treatment average: $52.3 \mathrm{t} \mathrm{ha}^{-1}$ ). The figure giving soil moisture content demonstrates the marked differences between the two years. In 1999 there were average values of 21 and $18.5 \%$ respectively, for the irrigated and dry treatments, while the soil 

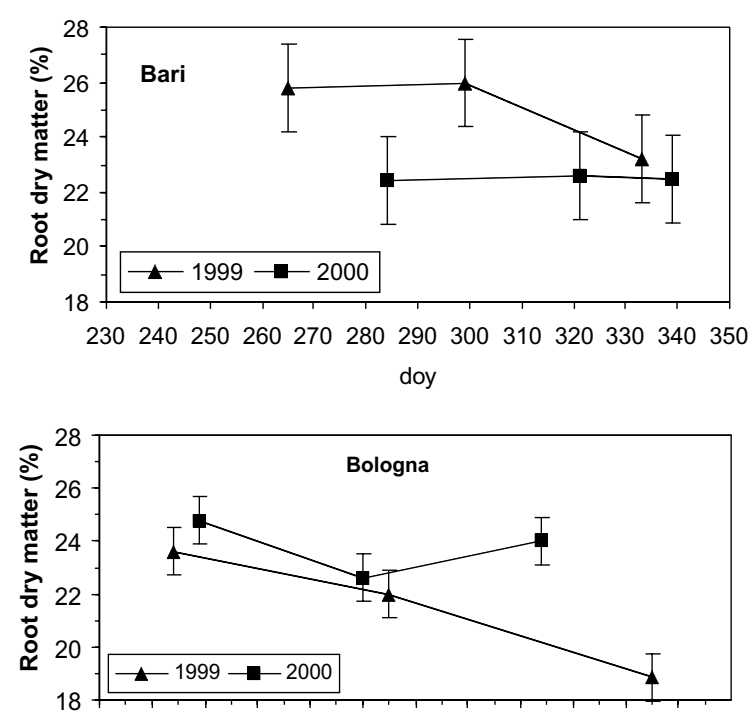

230240250260270280290300310320330340350

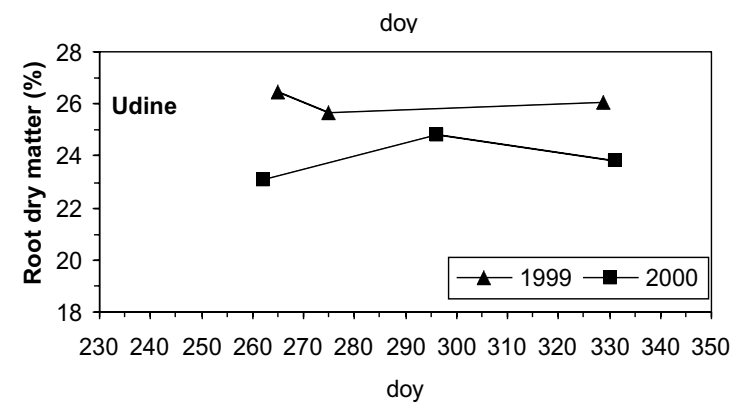

Figure 5. Effects of interaction Harvest time $\mathrm{x}$ Year on root dry matter content in Chicory, during 1999 and 2000. (doy $=$ day of the year). Symbols represent the three harvest times. Bars represent L.S.D. for $\mathrm{P}<0.05$, where not present the interaction is not significant.

moisture content in 2000 was 17.7 and $15.6 \%$ on average for irrigated and dry, respectively, with values, in the latter, as low as $9.1 \%$ in the first ten days of August (Figure 2).

In Rovigo the only statistically significant difference was the year effect, with 1999 being more productive $\left(60.5 \mathrm{t} \mathrm{ha}^{-1}\right)$ than $2000(48.4 \mathrm{t}$ $\left.\mathrm{ha}^{-1}\right)$. This result cannot be explained by a different seasonal trend, as it was almost identical in the two years, nor by temperatures (3087 and $3170{ }^{\circ} \mathrm{Cd}$ temperature sum in 1999 and 2000, respectively) nor rainfall (612 and $554 \mathrm{~mm}$ in 1999 and 2000, respectively) (Figure 1). The cause was probably the fact that, although sowing was done in both years in the first two weeks of April, in the first year crop emergence was on 110 doy, while in the following year it was on 122 doy. This delay, probably due to a different sowing depth, can be considered responsible for the lower yield, as found in other trials (Baert et al., 1997; Schittenhelm, 2001;), in which later emergences from the end of March onwards, even of just 15 days, caused significant yield reductions both in the same cultivar and in others.

3.1.2 Dry matter content of the roots. There was a significant effect of the interaction harvest time $\mathrm{x}$ year in Bari and Bologna. In both areas, at the 3rd harvesting time in 1999 there was a significant reduction in dry matter content (23.3 and $18.8 \%$ in Bari and Bologna, respectively) compared to the other harvests (Figure 5). In Udine, in both years, dry matter content in the roots was more or less constant for all three harvests, with values of between 23.1 and $26.5 \%$ (Figure 5).

3.1.3 Leaf production. In Bari, the interaction effect harvest time $\mathrm{x}$ year was statistically significant. In 1999 there was a progressive loss of leaf dry matter (leaf dehydration), with a reduction of about $40 \%$ of leaf dry weight between the 1st and 3rd harvests. Instead, there was an inverse trend in 2000, with the increase in leaf dry weight being statistically higher at the 3rd harvest time compared to the 1st (Figure 6). The reason for this was the late appearance of new leaves (re-growth), probably due to two heavy rainfall events in September (110 $\mathrm{mm})$ and October $(192 \mathrm{~mm})$, which are clearly visible in Figure 1. These rainfalls saturated the soil, causing problems of anoxia in the roots, which triggered the mechanism of leaf regrowth, with the return of normal water soil conditions. This was also encouraged by fairly mild temperatures during the period (maximums above $15{ }^{\circ} \mathrm{C}$ and minimums above $5{ }^{\circ} \mathrm{C}$ ).

The same event in Bari made the interaction year $\mathrm{x}$ irrigation treatments significant, with an effect of irrigation on leaf production (4.6 and $3.8 \mathrm{t} \mathrm{ha}^{-1}$, irrigated and dry treatments, respectively), which was only significant in 1999. In 2000 , the influence of irrigation was masked by the above-described re-growth process which occurred in all treatments between the 2nd and 3rd harvest following the two above-described rainfall events.

The significant interaction harvest time $\mathrm{x}$ year was also clear in Bologna (Figure 6). In 2000 leaf dry weight reduced over time $(-60 \%$ from the 1st to the 3rd harvests), while in 1999 
a)

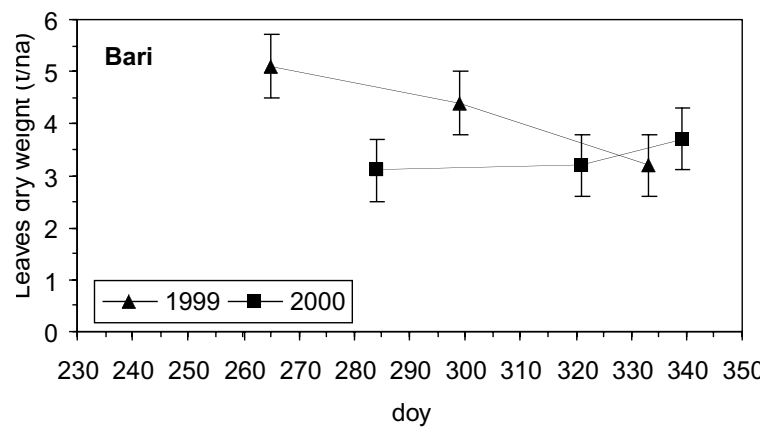

b)

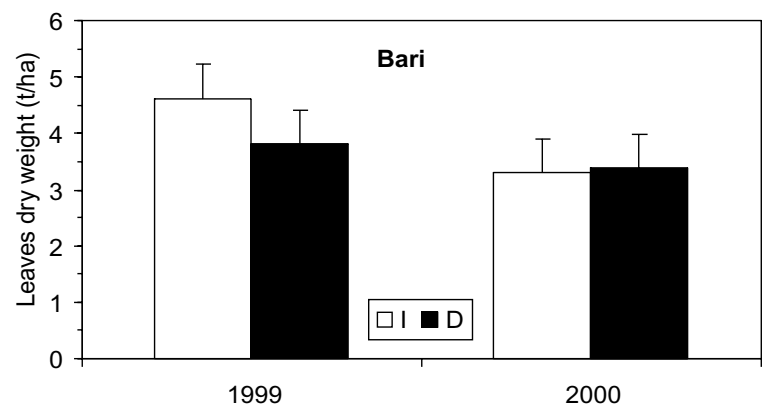

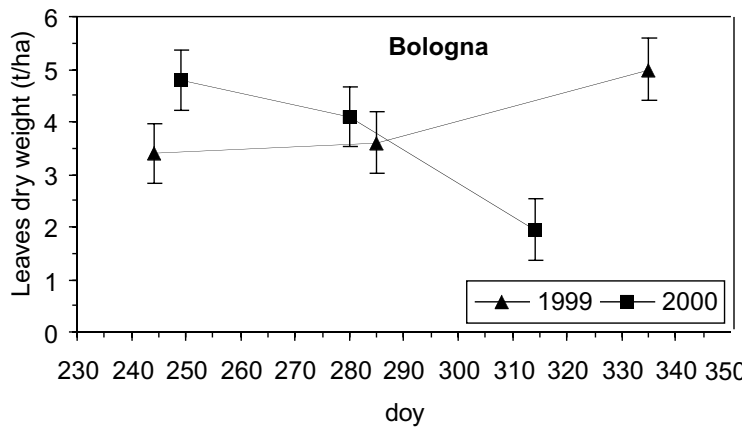

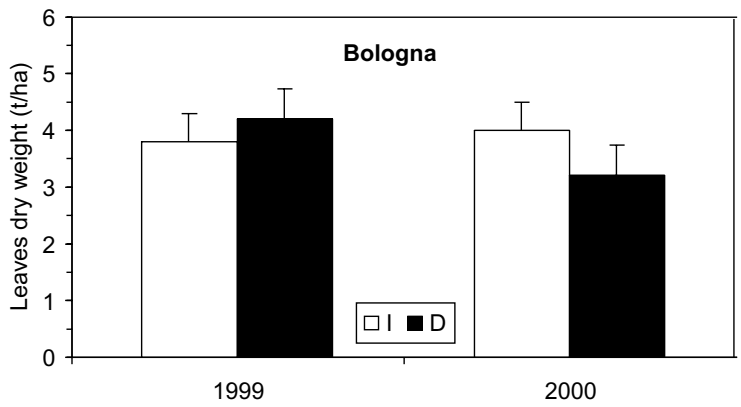

Figure 6. Effects of interaction Harvest time x Year (a) and Irrigation regime $\mathrm{x}$ Year (b), on yield of leaves in Chicory, during 1999 and 2000. (doy = day of the year). Symbols represent the three harvest times. I = with irrigation; D = dry regime. Bars represent L.S.D. for $\mathrm{P}<0.05$.

it remained constant for the first two harvests and then increased at the 3rd (Figure 6). Also in this case, two heavy rainfall events in rapid succession, in the first $(75 \mathrm{~mm})$ and second ten days $(89 \mathrm{~mm})$ of November, probably caused the same problems as in Bari, i.e. the growth of new leaves, in this case accompanied by a rapid and brusque lowering of the temperatures (Figure 1). In this environment the effect of the interaction harvest year $\mathrm{x}$ irrigation treatment was also significant. While in 2000 (the hotter drier year, with $462 \mathrm{~mm}$ of rainfall against $660 \mathrm{~mm}$ in 1999, and a temperature sum of 3004 against 2766 ${ }^{\circ} \mathrm{Cd}$ ), the total replacement of water lost by evapotranspiration led to higher leaf production, there was no effect in 1999, following the abovementioned growth of new leaves (Figure 6).

3.1.4 Sugar content and yield. In Bologna, in 2000, the total root sugar content (fructose + glucose) was 14.8 and $16.3 \%$ of the fresh weight, respectively, at the 1st (6 September) and 2nd harvest (7 October), with a total sugar production of about $10.0 \mathrm{t} \mathrm{ha}^{-1}$ and $8.4 \mathrm{t} \mathrm{ha}^{-1}$ of inulin (Figure 7). This is in agreement with what was obtained in previous studies in the same environment with the same variety (Amaducci and Pritoni, 1998). The differences, not statistically significant, and limited number of data prevent definite conclusions being drawn; however, previous experiments have demonstrated that neither time of sowing (Schittenhelm, 2001) nor harvest (Baert et al., 1997) influence sugar content, which is instead a specific characteristic of the variety grown and of the cropping environment.

The fructose/glucose ratio (DP), an index of the degree of polymerisation, lowered from 17.2 at the 1 st harvesting time to 9.6 at the $2 \mathrm{nd}$, with a statistically significant difference which confirms the results obtained in other trials, i.e., that delaying the harvest triggers a process of inulin depolymerisation in chicory roots (Dersch et al., 1993; Van Herck et al., 1992).

In Udine the total root sugar content reached maximum values in 1999, often above $20 \%$ of the fresh weight $(23.0,21.6$ and $19.3 \%$, respectively, at the 1st, 2nd and 3rd harvests), likewise the $3^{\text {rd }}$ harvest time in $2000(20.7 \%)$ (Figure 8). These values agree with the per- 

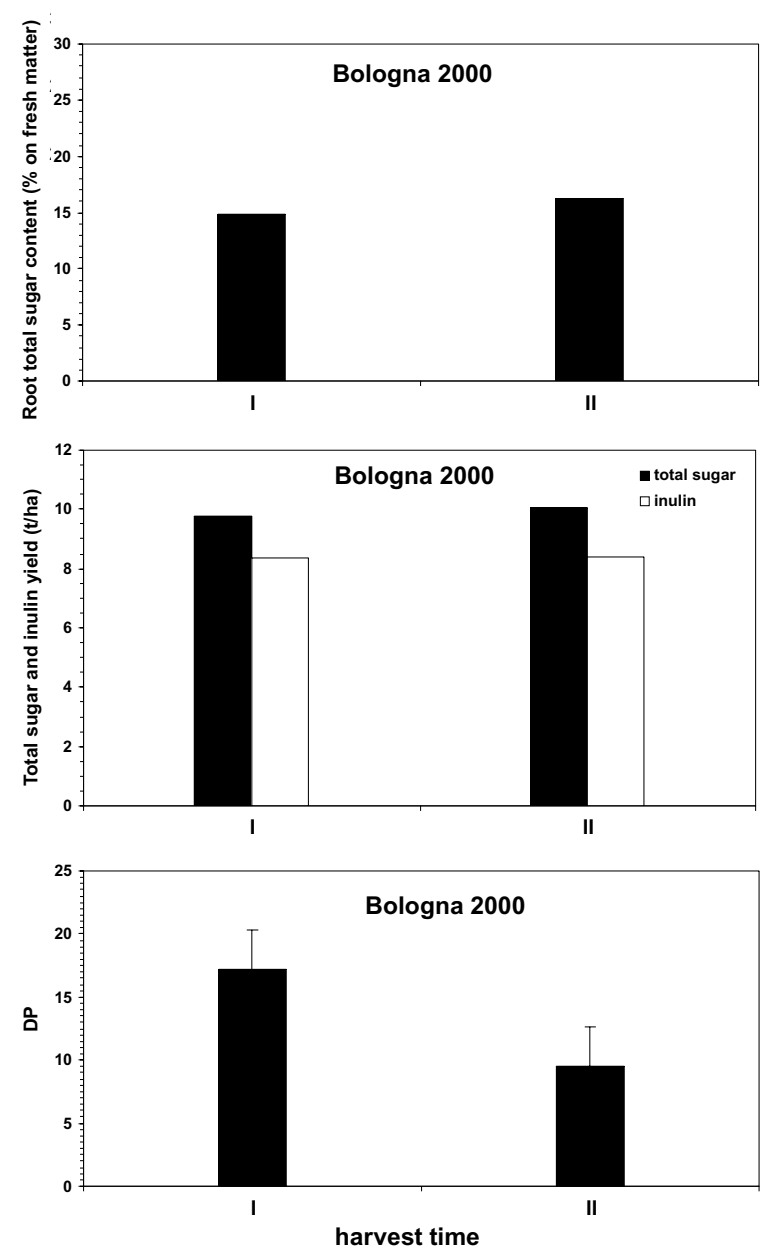

Figure 7. Effect of Harvest time on total sugar content, total sugar and inulin yield and degree of polymerisation of inulin (DP) in Chicory at Bologna in 2000. I and II represent the first and second harvest time, respectively. Bars represent L.S.D. for $\mathrm{P}<0.05$; where not present the interaction is not significant.

centages supplied by the same variety in two trials carried out between 1997 and 1999 in Brauaschweig (Germany) (Schittenhelm, 1999 and 2001).

The average DP of inulin was instead fairly low: in 1999 it was between 7.6 and 6.9 passing from the 1st to the 3rd time of harvest, while in 2000 these values varied between 2.8 and 4.8 . Total sugar yields in 1999 registered a minimum of 8.0 at the 1st harvest, and a maximum of 9.7 $\mathrm{t} \mathrm{ha}^{-1}$ at the $2 \mathrm{nd}$, while in 2000 they remained around 4.1-4.3 t ha-1 (Figure 8).

Inulin production showed a similar trend to that of total sugars, with statistically higher values in 1999 than 2000, and the maximum value
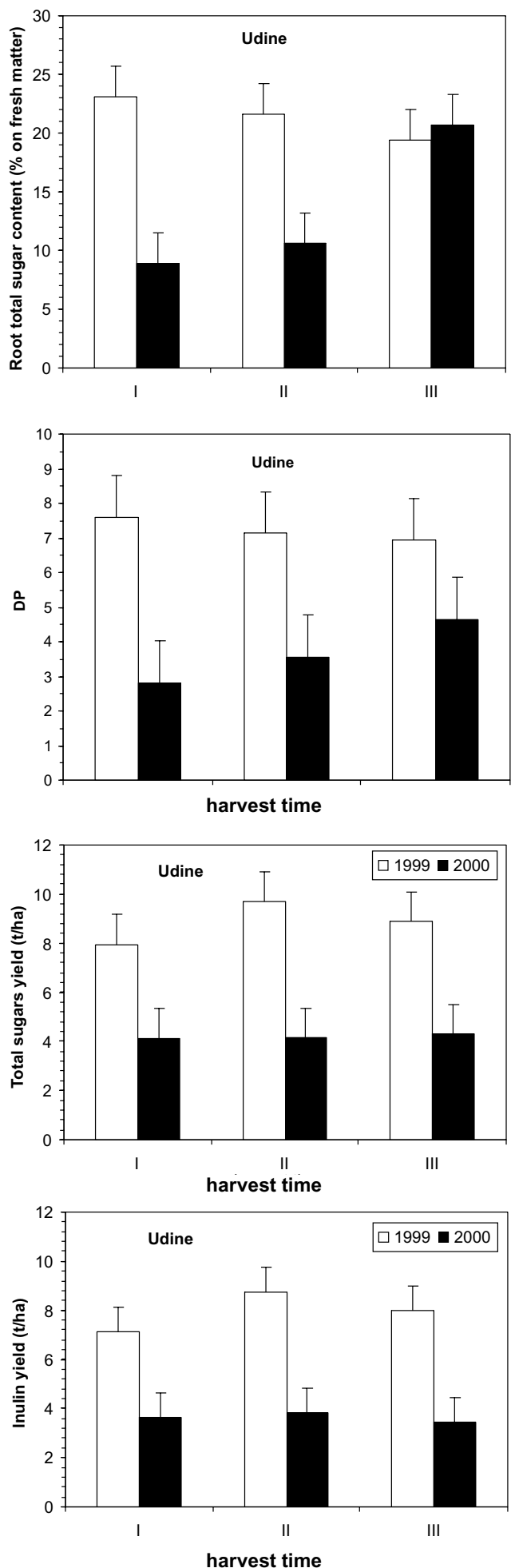

Figure 8. Effect of interaction Harvest time $\mathrm{x}$ Year on total sugar content, total sugar yield, degree of polymerisation of inulin (DP) and inulin yield in Chicory at Udine during 1999 and 2000. I, II and III represent the first, second and third harvest time, respectively. Bars represent L.S.D. for $\mathrm{P}<0.05$; where not present the interaction is not significant. 
at the 2nd harvesting time in $1999\left(8.7 \mathrm{t} \mathrm{ha}^{-1}\right)$, while in 2000 the values obtained were never above $4 \mathrm{t} \mathrm{ha}^{-1}$ (Figure 8).

\subsection{Jerusalem artichoke}

3.2.1 Tuber production. Obviously, the highest tuber yields were always those of the last harvest, but with yield differences compared to the $1^{\text {st }}$ harvesting time that were not constant over the two years. At Bari in 1999, there was a $62 \%$ increase in tuber fresh weight yield recorded at the 2nd harvest compared to the 1st, much higher than that registered in 2000 (11.8\%). This result was determined both by the exceptional yield obtained at the 2nd harvest in 1999 (90 t $\mathrm{ha}^{-1}$ ), the highest of the entire trial, and the lower tuber yield at the $1 \mathrm{st}\left(33.8 \mathrm{t} \mathrm{ha}^{-1}\right)$ compared to the same harvest in $2000\left(60.1 \mathrm{t} \mathrm{ha}^{-1}\right)$ (Figure 9 ). Given the same date of emergence, the fact that the harvest was 13 days earlier in 1999 (278 doy) compared to that of 2000 (291 doy), surely influenced these yield differences. In fact the delay in harvesting, if translated into temperature sum, is equal to the crop in 2000 having an extra $297{ }^{\circ} \mathrm{Cd}$ available during a phase of rapid tuber growth; which undoubtedly positively influenced yield.

In Jerusalem artichoke, the "dry" treatment included the application of $25 \%$ of the volume of water of the irrigated treatments (569 and $451 \mathrm{~mm}$ in 1999 and 2000, respectively). In this case the soil moisture content levels were clearly lower than those in the chicory, with average moisture contents of $15.4 \%$ and $14.6 \%$ for both irrigation treatments, in 1999 and 2000, respectively (Figure 2). This is due to the fact that Jerusalem artichoke has a higher soil water uptake capacity than chicory, especially in the deeper layers, thanks to a more "exploratory" root apparatus.

The same occurred in Bologna, where tuber production increased by $176 \%$ at the 2 nd time of harvest in 1999, and by $93 \%$ in 2000 (Figure 9).

These differences were not caused by the overly early date of the last tuber harvest in 2000 (7 November against 1 December in 1999), because the stalks at the last harvest had only $2.4 \%$ of total sugars compared to the previous $13 \%$, which would appear to indicate a complete translocation of assimilates (Figure 10). The cause might be the excess water applied to the crop in 2000. In fact, adding rainfall to the
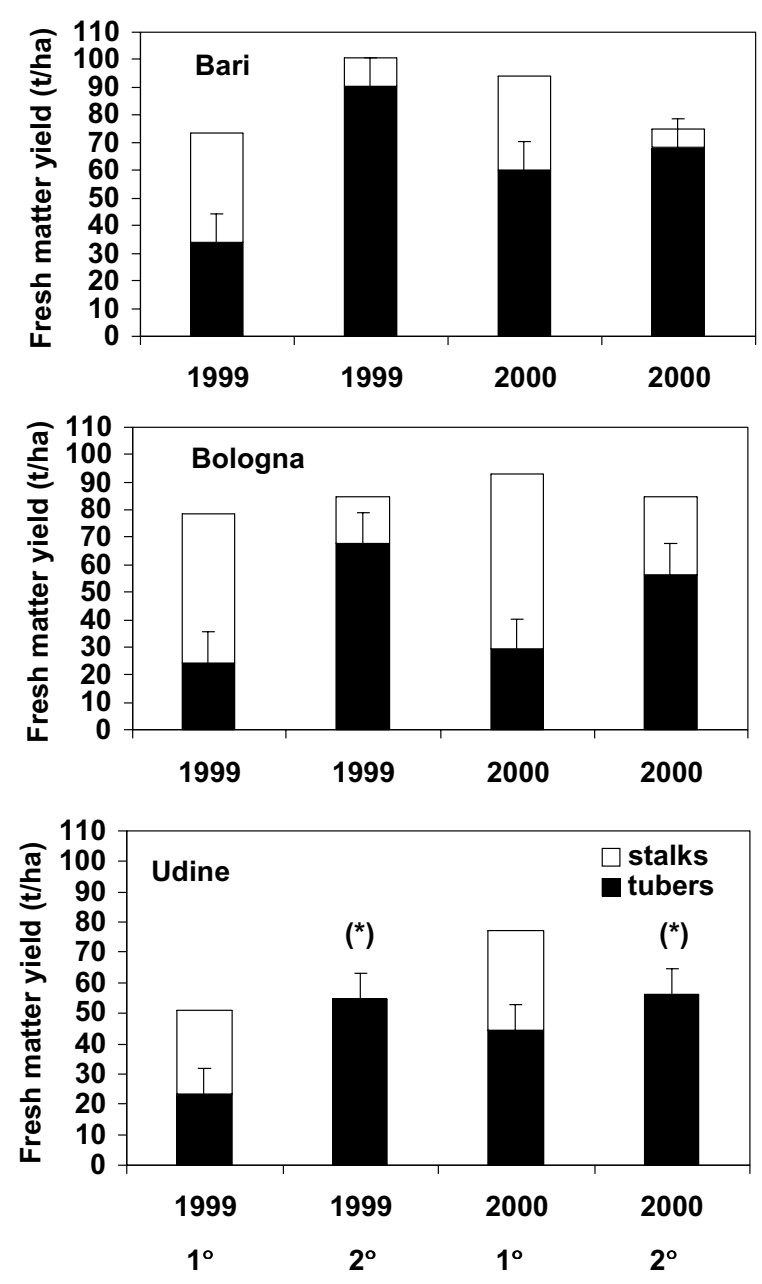

Figure 9. Effect of interaction Harvest time x Year on stalks and tuber yield of Jerusalem artichoke during 1999 and 2000. The two harvest times were: the first $\left(1^{\circ}\right)$ suitable for the stalks and the second $\left(2^{\circ}\right)$ for the tuber yield. $(*)$ for the production of stalks in Udine there was no 2nd harvest time. Bars represent L.S.D. for $\mathrm{P}<0.05$; where not present the interaction is not significant.

irrigations in that year gives $826 \mathrm{~mm}$, which can be considered excessive for the trial environment, in that the soil water content was around $28 \% \mathrm{v} / \mathrm{v}$ in the irrigated treatments and $24.7 \%$ in the dry, against $22.7 \%$ in 1999 for both treatments (Figure 2), and leading to a yield decrease. This confirms that Jerusalem artichoke is intolerant of excess water (Denoroy, 1996).

In Udine the highest yield differences were registered between 1st harvest times in the two years of trial. The last harvests supplied almost identical yields in the two years (54.9 and $56 \mathrm{t}$ ha $^{-1}$ in 1999 and 2000, respectively), while the 
tuber yields obtained at the 1st harvest in 1999 (23.5 $\mathrm{t} \mathrm{ha}^{-1}$ ) were markedly lower than those of the same harvest in 2000 (44.5 $\mathrm{t} \mathrm{ha}^{-1}$ ) (Figure 9). This result was due to unfavourable weather conditions and a 1st harvest 7 days later, corresponding to circa $109^{\circ} \mathrm{C}$ temperature sum (277 and 284 doy in 1999 and 2000, respectively).

The treatment with complete water replacement supplied the crop with 104 and $210 \mathrm{~mm}$ in 1999 and 2000, respectively, whereas in the dry treatment water was supplied when strictly necessary, 6 times in 1999 for a total of $49 \mathrm{~mm}$, and twice in 2000 for a total of $70 \mathrm{~mm}$ (Figure 3). Figure 3 also shows that Jerusalem artichoke has higher water consumption than chicory and at the same time is able to uptake, thanks to its architecture apparatus, the moisture in the soil, as happened in Bari. In Udine, Jerusalem artichoke, which was unable to explore the soil at depth, given the shallow active layer, soon exhausted the available moisture, reaching values close to wilting point (10.6\% in 1999).

Complete water replacement, while not influencing the tuber fresh matter yield, increased the tuber dry matter content in comparison with the dry treatments. This determined in the latter, a yield reduction of tubers in terms of dry weight (9.3 against $10.9 \mathrm{t} \mathrm{ha}^{-1}$ ), which was statistically significant and in agreement with the absolute values previously obtained in the same environment with the same variety (Paolini et al., 1996).

3.2.2 Stalks production. For the production of stalks in Udine, reference is only made to the 1st harvest time as there was no 2 nd harvest time in either year of the trial, these being at the end of the cycle, and therefore of interest only as residues.

In Bari the average harvest time effect, with the 1st time clearly higher than the 2nd (37.0 against $8.5 \mathrm{t} \mathrm{ha}^{-1}$ ) and the year effect were both statistically significant, with 1999 being more favourable for the production of stalks than 2000 (25.0 and $20.5 \mathrm{t} \mathrm{ha}^{-1}$ in 1999 and 2000, respectively). This result, mainly considering the 1 st harvest, is contrary to that obtained for tuber production in the same area, and is probably due to the very dry summer in 2000 as well as the different harvest dates (Figure 9).

In Bologna, time of harvest, with the 1st harvest time obviously more productive than the 2nd (58.7 and $22.4 \mathrm{t} \mathrm{ha}^{-1}$, respectively), year effect, with 2000 (40.15 $\left.\mathrm{t} \mathrm{ha}^{-1}\right)$ being more productive than 1999 (35.4 $\left.\mathrm{t} \mathrm{ha}^{-1}\right)$ and also irrigation regime were significant, with the irrigation, on average, determining a higher production of stalks than the dry treatment (45.6 and $35.6 \mathrm{t}$ $\mathrm{ha}^{-1}$, respectively). These results confirm that Jerusalem artichoke, in conditions of unlimited water availability, demonstrates low water use efficiency (WUE), because of poor stomatal regulation (Conde et al., 1991), just like other cultivated species (sunflower) belonging to the genus Helianthus (Morizet and Merrien, 1990). This determines high vegetative yields (stalks and leaves), which however does not translate into increases of the marketable product (in this case tubers), as demonstrated in this trial.

In Udine the higher production of stalks registered in 2000 (32.6 $\left.\mathrm{t} \mathrm{ha}^{-1}\right)$ than $1999\left(27.4 \mathrm{t} \mathrm{ha}^{-1}\right)$ appears to be due both to the better weather conditions in that year and also the slightly later ( 7 days) harvest $\left(+109^{\circ} \mathrm{Cd}\right.$ temperature sum), which benefited the still growing stalks.

3.2.3 Dry matter content in the tubers. There was a statistically significant effect of the interaction harvest time $\mathrm{x}$ year in Bari, with a very high dry matter content $(27.5 \%)$ at the 1 st harvest time in the first year (Figure 10) (the highest of the entire trial), also compared to those reported by other authors, in which the content varied between 12 and $24 \%$, with maximums of up to $26 \%$ in dwarf genotypes (Denoroy, 1996). The reason for this result could be the absence of significant rainfall and the intense sunshine in August and September, which are typical of this environment. This increased the mechanical resistance in the soil, which has frequently been indicated as being responsible for increases in dry matter in tubers (Denoroy, 1996), especially during a period of rapid growth.

In Bologna, the treatment effects harvest time $\mathrm{x}$ year and year $\mathrm{x}$ irrigation were statistically significant. In the former, the lowest dry matter content was recorded in the tubers (17\%) at the 2nd harvest in 1999 (335 doy), against the maximum recorded at the 1st harvest time in the same year (21\%) (Figure 10).

The irrigations, in 2000, did not determine significant variations in tuber dry matter content (18.9 and $19.2 \%$, in irrigated and dry, respectively), while in the first year of the trial 

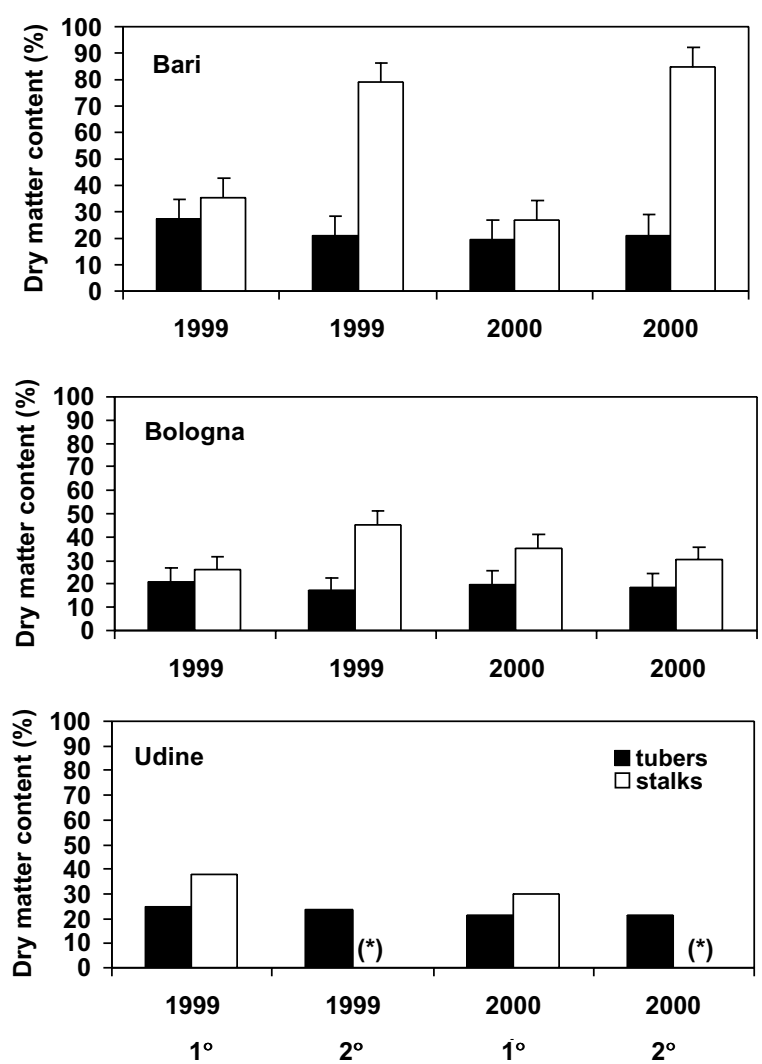

Figure 10. Effect of interaction Harvest time $\mathrm{x}$ Year on dry matter content in stalks and tubers of Jerusalem artichoke during 1999 and 2000. The two harvest times were: the first $\left(1^{\circ}\right)$ suitable for the stalks and the second $\left(2^{\circ}\right)$ for the tuber yield; $\mathrm{I}=$ with irrigation; $\mathrm{D}=$ dry regime; $(*)$ for the production of stalks in Udine there was no 2 nd harvest time. Bars represent L.S.D. for $\mathrm{P}<0.05$; where not present the interaction is not significant.

there was a statistically significant increase in the irrigated treatments (19.5 against $18.5 \%$ in dry) (Figure 10).

In Udine, in the first year of the trial, dry matter was statistically higher on average than that of 2000 ( 24.2 and $21.5 \%$, respectively). The complete water replacement irrigation, averaged over harvest times and years, determined a significant increase in tuber dry matter content compared to the dry treatment (24.2 and $21.5 \%$, respectively).

3.2.4 Dry matter content in the stalks. In Bari there was a significant effect of the interaction year $\mathrm{x}$ harvest time, with the dry matter content $(35.3 \%)$ of the 1 st harvest time of the first year being significantly higher than that of the same harvest time in 2000 (27.1\%). At the 2nd har- vest, in both years of the trial, the dry matter reached exceptionally high values (79.1 and $84.8 \%$, in the 1 st and 2 nd year, respectively), with completely dry stalks at harvest (Figure 10).

Also in Bologna the harvest time $\mathrm{x}$ year effect resulted as being significant, with the dry matter content in the stalks being higher at the 2nd harvest time than the 1st in 1999 (45.5 and $26 \%$, respectively), while in 2000 this percentage was higher at the $1^{\text {st }}$ harvest time with respect to the 2 nd ( 35.3 and $30.2 \%$, respectively) (Figure 10).

In Udine, the dry matter percentage in the stalks was higher on average in 1999 (37.8\%) than in 2000 (30\%) (Figure 10).

3.2.5 Content and production of sugars. In Bologna, total sugar content (fructose + glucose) was only analysed in 2000 and the interaction "water regime $\mathrm{x}$ harvest time" was not significant for all the analysed characters. Statistically significant differences were detected only between the two harvesting times, with the exception of the percentage of sugars in the tubers, almost identical at the two harvests (12.8 and $12.7 \%$, in the 1 st and $2 \mathrm{nd}$, respectively). In the stalks the sugar content of $13.6 \%$ at the 1 st harvest had practically disappeared by the 2 nd (2.4\%), by which time the stalks had ended their function as temporary storage organs (Figure 11).

The total production of sugars was highest at the 1 st harvest time when $12.4 \mathrm{t} \mathrm{ha}^{-1}$ of total sugars were obtained (hypothesising a wholeplant harvest of the crop, summing up the $8.7 \mathrm{t}$ $\mathrm{ha}^{-1}$ produced by the stalks and the $3.7 \mathrm{t} \mathrm{ha}^{-1}$ of the tubers), against the $7.1 \mathrm{t} \mathrm{ha}^{-1}$ obtained with the classical tuber harvest at the end of the cycle (Figure 11).

Inulin production was analogous: $10.2 \mathrm{t} \mathrm{ha}^{-1}$ was obtained with the whole-plant harvest of the crop at the 1st harvest time (3.2 and $7 \mathrm{t} \mathrm{ha}^{-1}$ from tubers and stalks, respectively), whereas the last harvest of tubers alone provided only $6.1 \mathrm{t} \mathrm{ha}^{-1}$ (Figure 11).

As regards the average DP of inulin, the highest values were registered in both tubers and stalks at the 1st harvest time (11.6 and 10.4, respectively). These values reduced to 8.9 and 7.1 for tubers and stalks, respectively, at the 2 nd harvest, because of depolymerisation phenomena. In Udine, the total sugar percentage in the tubers remained almost constant over both har- 

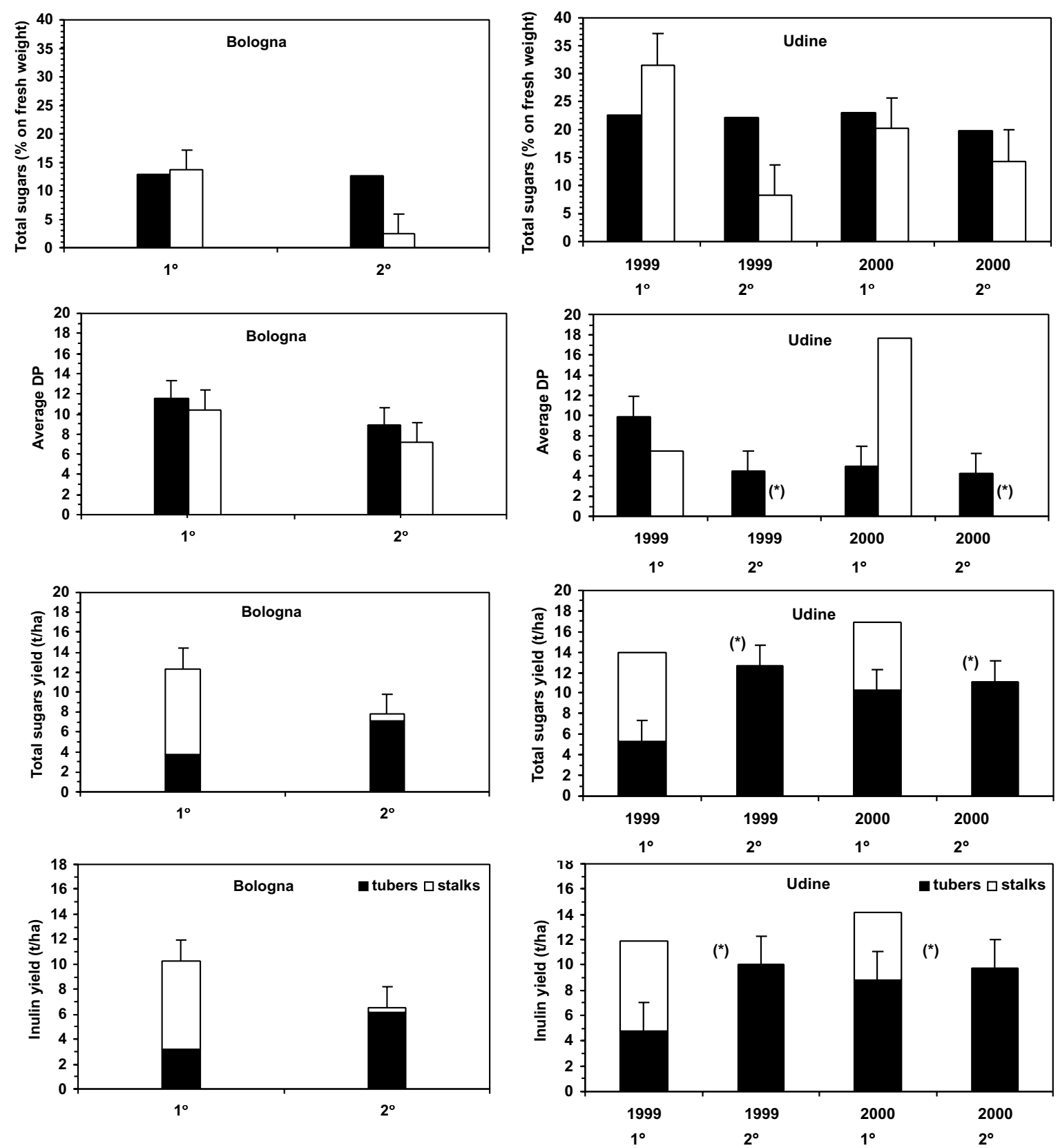

Figure 11. Effect of interaction Harvest time $\mathrm{x}$ Year on total sugar content, total sugar yield, inulin yield and average degree of polymerisation (DP) for stalks and tubers of Jerusalem artichoke at Udine during 1999 and 2000. Effects of differences in harvest time at Bologna during 2000. The harvest times were: the first $\left(1^{\circ}\right)$ suitable for the stalks and the second $\left(2^{\circ}\right)$ for the tuber yield. $(*)$ for the production of stalks in Udine there was no 2 nd harvest time. Bars represent L.S.D. for $\mathrm{P}<0.05$; where not present the interaction is not significant.

vest times and years, being much higher here than in Bologna, with average values in both years around $20 \%$.

The sugar content in the stalks reached at the 1 st harvest $31.6 \%$ in 1999 and $20.2 \%$ in 2000 , decreasing at a very low levels by the 2 nd harvest (Figure 11). Considering the wholeplant harvest of the crop (stalks and tubers), total sugar production was 13.0 and $16.9 \mathrm{t} \mathrm{ha}^{-1}$, in 1999 and 2000, respectively, whereas production with the harvest of tubers alone at the end of the cycle (2nd harvesting time) was 12.7 and 
$11.1 \mathrm{t} \mathrm{ha}^{-1}$ in 1999 and 2000, respectively, with a significant difference in the second year of experimentation (Figure 11).

Similarly, higher inulin yields were always obtained with the whole-plant harvest (tubers and stalks) compared to the traditional one (11.9 against $10 \mathrm{t} \mathrm{ha}^{-1}$ in 1999, and 14.1 against $9.7 \mathrm{t} \mathrm{ha}^{-1}$ in 2000) (Figure 11). The length of the inulin chain was shorter than that obtained in Bologna, with the exception of the value of stalks at the 1st harvest time in 2000 (17.6) (Figure 11). The average values of DP in tubers were fairly low, being between 4.2 and 4.9 (with the exception of 9.9 at the 1st harvest in 1999), and always denoting the tendency to a reduction passing from the 1 st to the 2 nd time of harvest with the delaying of the harvest date.

\section{Conclusions}

The results obtained in the two years of the trial allow aspects of the yield potential for the two crops of the examined environments to be evaluated. The Bologna area had the highest potential in terms of chicory root production, with an average yield of $65.6 \mathrm{t} \mathrm{ha}^{-1}$ (in fresh weight), and higher than that of Rovigo (54.4 tha ${ }^{-1}$ ), Bari $\left(46.5 \mathrm{t} \mathrm{ha}^{-1}\right)$ and Udine (38.7 $\left.\mathrm{t} \mathrm{ha}^{-1}\right)$. In Bologna, where the pedo-climatic characteristics appeared to make the use of irrigation superfluous, the highest production of the entire research project was obtained $\left(85.3 \mathrm{t} \mathrm{ha}^{-1}\right)$ corresponding to a very late harvest time (336 doy) which had never been experimented before. On the other hand, excessively delaying the harvest also involved risks, such as a late attack by leaf pathogens, like that of Sclerotinia spp. at Udine in 2000 , which was particularly negative in terms of production.

For the final yield of Jerusalem artichoke tubers, the Bari environment was the most productive with an average (treatments and years) of $80 \mathrm{t} \mathrm{ha}^{-1}$, followed by Bologna $\left(61 \mathrm{tha}^{-1}\right)$ and Udine (55.5 $\left.\mathrm{t} \mathrm{ha}^{-1}\right)$. This crop adapts well to a hot arid climate, such as that in the south of Italy, on condition that the limited water availability is compensated for by a good soil depth and a water table within reach of the good "exploratory" capacities of its root apparatus.

When Jerusalem artichoke is instead considered as a crop for whole-plant harvest (stalks and tubers), as recently suggested by some au- thors (Baldini et al., 2004), with very early harvesting (pre-flowering stage), Bologna, with the high stalk yields (58.7 $\left.\mathrm{t} \mathrm{ha}^{-1}\right)$ compared to Bari (37.0 $\mathrm{t} \mathrm{ha}^{-1}$ ) and Udine (29.5 $\left.\mathrm{t} \mathrm{ha}^{-1}\right)$, becomes the most suitable area. Adding the tuber yields to these values, average total fresh weight productions of $85.5 \mathrm{t} \mathrm{ha}^{-1}$ are reached in Bologna, 83.9 $\mathrm{t} \mathrm{ha}^{-1}$ in Bari, and $64.0 \mathrm{t} \mathrm{ha}^{-1}$ in Udine, higher than that of tubers alone at the last harvest. The high water availability characterising the pedoclimatic environment of Bologna in both years of the trial, while not being favourable for the production of tubers alone, instead encouraged the vegetative growth of the plant, especially the stalks. This type of harvest was also more productive in terms of sugar (and inulin) yield compared to the traditional tubers alone, in both Bologna (12 t ha-1 against $7.1 \mathrm{t} \mathrm{ha}^{-1}$ ), and Udine (15 $\mathrm{t} \mathrm{ha}^{-1}$ against $11.9 \mathrm{t} \mathrm{ha}^{-1}$ ), extending the length of the harvest season.

One very interesting result was that the total sugar content in the different organs analysed (roots, stalk and tubers) was always higher, for both crops, in Udine compared to Bologna. It is likely that these differences could be related to the different soil characteristics of the areas. In fact a loose shallow soil, with a high gravel content and subject to water stress, like that of Udine, could encourage metabolism of the fructans, regulated by the availability of sucrose (Denoroy, 1996), as happens in sugarbeet.

Lastly, the length of the inulin chain (average DP) has been confirmed as reducing, in both crops, with the delaying of the harvest date.

\section{Acknowledgements}

The research was financed by the MURST PRIN Project "Colture per la produzione da inulina: modelli di risposta ambientale e strategie colturali", Co-ordinator: Prof. Francesco Danuso. Grateful thanks go to Dr. Maurizio Turi, Dr. Marco Sandonà and Dr. Thamasebi Enferadi Sattar for technical assistance in the field and laboratory analyses for the Udine WG. Thanks are also due to Dr. Biancardi for having co-ordinated the work of the Rovigo WG and for his extremely useful comments to the manuscript.

\section{References}

Amaducci S., Pritoni G. 1998. Effect of harvest date and cultivar on Chicorium intybus yield components in north Italy. Ind. Crops Prod., 7:345-349. 
Baert J.R.A. 1997. The effect of sowing and harvest date and cultivar on inulin yield and composition of chicory (Chicorium intybus L.) roots. Ind. Crops Prod., 6:195-199.

Baldini M., Danuso F., Turi M., Vannozzi G.P. 2004. Evaluation of new clones of Jerusalem artichoke ( $\mathrm{He}$ lianthus Tuberosus L.) for inulin and sugar yield from stalks and tubers. Ind. Crop Prod., 19:25-40.

Conde J.R., Tenorio J.L., Rodriguez-Maribona B., Ayerbe L. 1991. Tuber yield of Jerusalem artichoke (Helianthus Tuberosus L.) in relation to water stress. Biomass Energy, 1:137-142.

D'Egidio M.G., Cecchini C., Cervigni T., Donini B., Pignatelli V. 1998. Production of fructose from cereal stems and polyannual cultures of Jerusalem artichoke. Ind. Crops Prod., 7:113-119.

Danuso F., Sandonà M., Turi M., Baldini M. 2002. Produttività e prospettive per le colture da inulina. Rivista di Agronomia, 26:33-41.

Danuso F. 2001. Le colture per la produzione di inulina: attualità e prospettive. L'Informatore Agrario, 3:176-187.

Denoroy P. 1996. The crop physiology of Helianthus Tuberosus L.: a model orientated view. Biomass Bioenergy, 11:11-32.

Dersch G., Kammerer S., Praznik W. 1993. Harvest dates and varietal effects on yield, concentration and composition of carbohydrates in chicory roots. Proceedings 2nd European Symposium on Industrial Crops and Products, 22-24 November, Pisa, Italy.
Di Candilo M., Giordano I., Biancardi E., Parisi B. 1997. Adattabilità ambientale e potenzialità produttive della cicoria da industria in Italia. Rivista di Agronomia, 31:651-657.

Fuchs A. 1993. Inulin and inulin containing crops. In: Elsevier (ed.): Studies in Plant Science, Vol. 3, 1- 417. Amsterdam, Holland.

Morizet J., Merrien A. 1990. Principaux traits du comportement hydrique du tournesol. In: Cetiom (ed.): Le tournesol et l'eau, 7-20. Paris, France.

Paolini R., Del Puglia S., Abbate V., Copani V., Danuso F., De Mastro G., Losavio N., Marzi V., Molfetta P., Pignatelli V., Venezia G., Vonella A.V. 1996. Produttività del topinambur (Helianthus tuberosus L.) in relazione a fattori agronomici diversi. Agricoltura Ricerca, XVIII, 163:126-144.

Schittenhelm S. 1999. Agronomic performance of root chicory, Jerusalem artichoke and sugar beet in stress and nonstress environments. Crop Sci., 39:1815-1823.

Schittenhelm S. 2001. Effect of sowing date on performance of root chicory. European Journal of Agronomy, 15:209-220.

Van Herck J.C., Coppens d'Eeckenbrugge G., Dutilleul P. 1992. Evolution des composantes du rendement en fructose de la racine de chicoreè indutrielle au cours de la campagne de recolte. Rev. Agric., 45:8-18.

Van Waes C., Baert J., Carlier L., Van Bockstaele E. 1998. A rapid determination of the total sugar content and the average inulin chain length in roots of chicory (Cichorium intybus L.). J. Sci. Food Agric., 76:107-110. 